\title{
PENYELENGGARAAN PEMERINTAHAN DESA DALAM PERSPEKTIF DESENTRALISASI ADMINISTRATIF DAN DESENTRALISASI POLITIK
}

\section{THE OPERATION OF VILLAGE GOVERNMENT IN PERSPECTIVE ADMINISTRATIVE DECENTRALIZATION AND POLITICAL DECENTRALIZATION}

\author{
Didik G. Suharto \\ Jurusan Ilmu Administrasi FISIP Universitas Sebelas Maret Surakarta \\ Jalan Ir. Sutami 36A, Surakarta \\ e-mail: didikgsuharto@yahoo.com \\ Diterima: 6 Juli 2012; direvisi: 6 Agustus 2012; disetujui: 10 Agustus 2012
}

\begin{abstract}
Abstrak
Penelitian ini bertujuan untuk menganalisis penyelenggaraan pemerintahan desa dalam perspektif desentralisasi administratif dan politik. Penelitian ini memiliki tipe deskriptif kualitatif. Pembatasan ruang lingkup penelitian meliputi: pembatasan periode waktu, lokasi, dan fokus analisis. Jenis data yang diperlukan ialah data primer dan data sekunder. Pengumpulan data dilakukan melalui wawancara, observasi, dan dokumentasi. Teknik analisis data dengan cara teknik analisis isi dan teknik analisis fenomenologi. Uji keabsahan data meliputi: uji validitas internal, validitas eksternal, reliabilitas, obyektivitas. Berdasarkan hasil dan pembahasan penelitian dapat dirumuskan beberapa kesimpulan, mencakup: penyelenggaraan pemerintahan desa; perubahan struktur dan fungsi kelembagaan dalam penyelenggaraan pemerintahan desa; dan kemandirian desa.
\end{abstract}

Kata kunci: desentralisasi, struktur, fungsi, kemandirian, desa

\begin{abstract}
This research aims to analyze the implementation of the village government organization in political and administrative decentralization perspective. This study is a descriptive qualitative research. The limitation of research scope includes: time period, location, and analysis focus limitation. The types of data needed were primary and secondary data. The data collection was done using interview, observation, and documentation. Technique of analyzing data used was content analysis and phenomenological analysis. The data validity test includes: internal and external validity test, reliability and objectivity test. Based on the result and discussion of research, it can be concluded that, include: the implementation of the village government organization; the structural and functional change of institution; and the village self-sufficiency.

Keywords: decentralization, structure, function, self-sufficiency, village
\end{abstract}

\section{PENDAHULUAN}

Selama ini desa masih sering terabaikan dalam penyelenggaraan pemerintahan dan pembangunan. Di berbagai aspek kehidupan, khususnya sosial/ekonomi, desa dan masyarakatnya masih berada pada kondisi serba kekurangan, jauh tertinggal dibanding kondisi masyarakat di perkotaan. Tata kelola pemerintahan desa dipandang sangat menentukan kemajuan desa atau peningkatan kesejahteraan masyarakat desa. Sehingga sudah semestinya pembenahan terhadap tata kelola pemerintahan desa menjadi fokus agenda bangsa Indonesia.

Terdapat tiga permasalahan utama dalam tulisan ini (diadopsi dari Suharto, 2012a). Pertama, keberadaan desa belum mampu mewujudkan kesejahteraan masyarakat desa. Eksistensi desa dianggap ambivalen dan cenderung kabur. UU Nomor 32/2004 tentang Pemerintahan Daerah belum memiliki landasan pijakan kuat untuk mengarah pada pencapaian cita-cita desa yang mandiri, demokratis dan sejahtera. Dari aspek teoritis, terdapat sejumlah ketidakjelasan dalam sistem pemerintahan desa sekarang ini. Misalnya dalam hal kewenangan. Menurut pasal 206 UU Nomor 32/2004, ada empat urusan pemerintahan desa: (a) Urusan yang sudah ada berdasarkan hak asal-usul desa; (b) Urusan yang menjadi kewenangan kabupaten/kota yang diserahkan pengaturannya kepada desa; (c) Tugas pembantuan dari pemerintah, propinsi, dan/atau pemerintah kabupaten/kota; dan (d) Urusan pemerintahan lainnya yang oleh peraturan perundang-undangan diserahkan kepada desa. Ketentuan tersebut mempunyai arti bahwa undang-undang memberi amanat kepada kabupaten/kota untuk melakukan "desentralisasi" kewenangan kepada desa. Menurut teori desentralisasi dan hukum tatanegara, mekanisme itu menimbulkan kekacauan logika dan hukum. Permasalahan lain adalah menyangkut titik berat otonomi pada daerah kabupaten/kota, yang berimplikasi terhadap dominansi 
pemerintah kabupaten/kota ke desa. Undang-undang Dasar (UUD) RI 1945 sebenarnya tidak eksplisit mengamanatkan undang-undang untuk menempatkan desa dalam sub sistem kabupaten/kota, tetapi UU Nomor 32/2004 ternyata menempatkan desa dalam sub sistem kabupaten/kota. Desain penempatan desa tersebut berdampak terhadap marginalisasi desa.

Kedua, struktur dan fungsi kelembagaan pemerintahan desa belum sesuai kebutuhan desa dan masyarakatnya. Perubahan struktur dan fungsi kelembagaan yang sering terjadi selama ini pada kenyataannya belum memperjelas posisi (kedudukan) dan kewenangan desa. Meskipun perubahan kebijakan desentralisasi berimplikasi terhadap perubahan struktur dan fungsi kelembagaan, namun perubahan struktur dan fungsi itu belum sesuai tuntutan organisasi dan masyarakat. Dalam realitasnya, polemik-polemik yang terkait persoalan kelembagaan masih berulang kali terjadi di internal desa maupun dengan supra desa. Misalnya soal kewenangan, keuangan, dan pembangunan. Pelayanan publik kepada masyarakat desa nyata-nyata juga masih banyak dikeluhkan, misalnya dalam pengurusan administrasi yang berbelit, jam kerja kantor yang tidak jelas, dan adanya pungutan-pungutan. Beragam persoalan pemerintahan desa itu pada intinya bersumber pada struktur dan fungsi kelembagaan pemerintahan desa yang masih "bermasalah". Untuk menentukan struktur dan fungsi kelembagaan yang sesuai kebutuhan masyarakat atau organisasi tidak mudah. Secara teoritis, belum ada pedoman atau ukuran-ukuran baku untuk mengidentifikasi struktur dan fungsi kelembagaan pemerintahan desa yang sesuai kebutuhan masyarakat/organisasi. Juga belum ada pengelompokan bentuk atau klasifikasi desa sebagai wujud keberagaman karakteristik desa yang bisa diterima luas.

Ketiga, desain kebijakan penyelenggaraan pemerintahan desa belum mengarah kepada perwujudan kemandirian desa. Meskipun secara legal formal persoalan kemandirian desa tidak eksplisit dinyatakan dalam peraturan perundang-undangan sebagai sasaran yang harus dituju, namun dari sisi filosofis, historis, dan strategis, kemandirian desa merupakan suatu hal yang sangat penting. Perspektif umum dari penelitian ini berpandangan bahwa faktor struktural dan fungsional kelembagaan dinilai memiliki pengaruh untuk menjembatani sejumlah persoalan yang telah diuraikan di atas. Mencermati kondisi pemerintah desa beserta masyarakatnya, maupun permasalahan empiris dan teoritis yang dihadapi desa saat ini, dapat disimpulkan bahwa desain kebijakan desentralisasi terkait struktur dan fungsi kelembagaan pemerintahan desa pada kenyataannya belum mampu mendorong kemandirian. Beranjak dari pemaparan sebelumnya, ada harapan untuk mengevaluasi dan menata sistem penyelenggaraan pemerintahan desa secara menyeluruh.
Penelitian empiris ini secara umum diharapkan mampu menjawab permasalahan: "bagaimanakah penyelenggaraan pemerintahan desa dalam perspektif desentralisasi administratif dan desentralisasi politik?". Oleh karena itu, studi ini bertujuan untuk menganalisis penyelenggaraan pemerintahan desa dalam perspektif desentralisasi administratif dan desentralisasi politik. Analisis untuk menjawab permasalahan penelitian juga dikaitkan dengan persoalan perubahan struktur dan fungsi kelembagaan pemerintahan desa dan kemandirian desa.

\section{METODE PENELITIAN}

Penelitian ini bertipe deskriptif, yang merupakan reinterpretasi obyektif tentang fenomenafenomena sosial di seputar permasalahan yang diteliti. Penelitian ini juga bersifat kualitatif, yakni mendasarkan pada pengamatan-pengamatan lapangan non kuantitatif dan dianalisis dengan cara non statistik. Dilakukan melalui pengamatan langsung dan wawancara yang relatif tidak terstruktur (fleksibilitas, spontanitas, dan terbuka).

Pembatasan ruang lingkup penelitian ditujukan untuk lebih memfokuskan analisis, menajamkan pokok bahasan, dan mendapatkan kedalaman penelitian. Dari aspek batasan waktu, ruang lingkup penelitian difokuskan pada periode berlakunya UU Nomor 32/2004 tentang Pemerintahan Daerah dan PP Nomor 72/2005 tentang Desa. Meski demikian, penelitian juga memperbandingkan beberapa hal terkait fokus analisis dengan peraturan perundangundangan saat berlakunya UU Nomor 5 tahun 1979 tentang Pemerintahan Desa dan UU Nomor 22 tahun 1999 tentang Pemerintahan Daerah. Sedangkan lokasi penelitian dibatasi di Kabupaten Boyolali Jawa Tengah, khususnya di Desa Catur (Kecamatan Sambi), Desa Krasak (Kecamatan Teras), dan Desa Bendan (Kecamatan Banyudono). Sementara ruang lingkup analisis penelitian dibatasi pada persoalan penyelenggaraan pemerintahan desa dalam perspektif desentralisasi administratif dan desentralisasi politik, serta mengkaitkannya dengan perubahan struktur dan fungsi kelembagaan pemerintahan desa dan kemandirian desa.

Data-data yang dibutuhkan dikumpulkan melalui berbagai cara, yaitu: (1) Wawancara. teknik wawancara dalam penelitian ini adalah wawancara mendalam (indepth interview) melalui tanya jawab secara langsung antara pewawancara dengan informan atau orang yang diwawancarai. Narasumber dalam penelitian ditentukan secara purposive; (2) Observasi. Kegiatan yang menjadi obyek observasi adalah berbagai hal yang berhubungan dengan penyelenggaraan pemerintahan desa; (3) Dokumentasi. diantaranya adalah: produk peraturan perundang-undangan di tingkat nasional (UU, PP, Keppres, Kepmen, dan lain-lain); tingkat daerah (Perda dan Keputusan Bupati); dan tingkat desa (Perdes); risalah-risalah rapat; data pertumbuhan desa 
secara nasional; data tentang situasi sosial politik secara umum; data tentang kondisi geografis; demografis; sosial ekonomi; dan kebijakan daerah Kabupaten Boyolali serta data-data tentang kelembagaan dan proses penyelenggaraan pemerintahan desa, termasuk APBDesa, RPJMDesa, dan LKPj Kepala Desa.

Analisis data dilakukan melalui dua cara, yaitu teknik analisis isi (content analysis) dan teknik analisis fenomenologi. Teknik analisis isi dan fenomenologi digunakan saling melengkapi untuk menjawab permasalahan penelitian. Uji keabsahan data dalam penelitian kualitatif meliputi uji credibility (dilakukan dengan memperpanjang pengamatan, peningkatan ketekunan dalam penelitian, triangulasi, pemanfaatan bahan referensi, dan member check), transferability (melalui pembuatan laporan dengan uraian rinci, jelas, sistematis, dan dapat dipercaya), dependability (melalui proses pembimbingan yang terus menerus untuk mempertahankan konsistensi), dan confirmability (melalui proses pengujian secara bertahap untuk mendapatkan kebenaran hasil penelitian).

\section{HASIL DAN PEMBAHASAN}

Konstruksi yang dibangun dalam mengatur pemerintahan daerah sama dengan konstruksi yang dibangun dalam mengatur pemerintahan desa. Konstruksi desentralisasi tersebut dapat didekati dari perspektif politik dan administratif. Desentralisasi politik pada saat berlakunya UU Nomor 5/1979 tentang Pemerintahan Desa dalam tataran regulatif maupun empiris berlangsung dengan sangat minimal. Sebaliknya, ketika berlaku UU Nomor 22/1999 desentralisasi politik berlangsung dinamis. Sedangkan pada era berlakunya UU Nomor 32/2004 sampai dengan saat ini, desentralisasi politik dan administratif secara regulatif/empirik dicoba diseimbangkan dengan mengurangi penekanan pada desentralisasi politik. Hal tersebut juga didukung oleh pendapat Eko (2005), USAID DRSP (2006), dan penelitian Zuhro (2009).

Pergeseran penekanan desentralisasi politik dan desentralisasi administratif dari sudut regulatif maupun empirik saat sekarang dapat dilihat antara lain dari mekanisme pemilihan perangkat desa. Dari sisi desentralisasi politik mengalami penurunan muatan karena penduduk desa lebih terbatas mewujudkan kedaulatan dalam memilih pemimpin. Di sisi berbeda, bobot desentralisasi administrasi semakin bertambah karena dengan melalui mekanisme pemilihan ujian/seleksi, proses bisa berjalan efektif dan efisien, rendah konflik, dan kualitas calon lebih mudah diarahkan. Demikian pula dalam hal mekanisme pemilihan dan tugas/fungsi BPD. Pengangkatan atau pengisian sekretaris desa dari PNS kurang lebih juga membawa implikasi semacam itu. Desentralisasi politik semakin melemah, desentralisasi administratif semakin menguat. Dalam kaitan pengaturan pengelolaan tanah bengkok dan perubahan sistem penggajian kepala desa/perangkat desa, bisa pula dimaknai dari sudut pandang pergeseran desentralisasi politik dan desentralisasi administratif.

Lemahnya eksistensi desa dikarenakan desa tidak memiliki sumber daya memadai untuk menggerakkan kesempatan/peluang yang menjadi nilai lebih desentralisasi. Persoalan pokoknya, posisi/kedudukan desa yang tidak jelas. Kedudukan desa sejak UU Nomor 1 tahun 1945 tentang Kedudukan Komite nasional Indonesia Daerah sampai dengan peraturan perundang-undangan yang terakhir (UU Nomor 32 tahun 2004), tidak memiliki posisi yang kuat. Pondasi yang mendasari kedudukan desa tidak kuat/jelas. Regulasi-regulasi yang pernah ada berkontribusi atas desain kedudukan desa yang tidak jelas. Ketidakjelasan kedudukan desa berpengaruh terhadap aspek-aspek yang lain. Kedudukan desa akan sangat menentukan kewenangan desa, hubungan desa dengan supra desa, susunan pemerintahan desa, maupun sumber-sumber keuangan desa.

UU Nomor 5/1979 menempatkan desa sebagai obyek pemerintah. Undang-undang ini menjadi alat kontrol negara terhadap masyarakat lokal, dengan cara menciptakan keseragaman desa di seluruh Indonesia untuk memudahkan pengawasan dan pengaturan. Perspektif desa administratif (local state government) sangat menonjol dalam UU Nomor 5/1979. Undangundang tersebut di kritik oleh banyak pakar (Antlov, 2001; Santoso, 2003; Eko (ed.), 2005; Manan, 2004; Tjondronegoro, 1999; dan Mas'oed, 2003) memiliki berbagai kelemahan.

UU Nomor 22/1999 tentang Pemerintahan Daerah merubah secara radikal sistem pemerintahan desa. Menurut pasal 5 UU Nomor 22/1999, kewenangan desa mencakup: (1) Kewenangan yang sudah ada berdasarkan hak asal-usul desa; (2) Kewenangan yang oleh peraturan perundangperundangan yang berlaku belum dilaksanakan oleh daerah dan pemerintah; dan (3) Tugas pembantuan dari pemerintah, pemerintah propinsi, dan/atau pemerintah kabupaten. Sedangkan urusan pemerintahan desa menurut UU Nomor 32/2004 tentang Pemerintahan Daerah pasal 206 meliputi: (a) Urusan yang sudah ada berdasarkan hak asal-usul desa; (b) Urusan yang menjadi kewenangan kabupaten/kota yang diserahkan pengaturannya kepada desa; (c) Tugas pembantuan dari pemerintah, pemerintah propinsi, dan/atau pemerintah kabupaten/kota; dan (d) Urusan lainnya yang oleh peraturan perundang-perundangan diserahkan kepada desa.

Namun, dalam realitasnya kewenangan berdasarkan hak asal-usul desa dapat dikatakan tidak ada. Kewenangan berdasarkan hak asal-usul desa sudah terlanjur hilang, terutama setelah berlakunya penyeragaman bentuk desa oleh UU Nomor 5/1979. Urusan-urusan yang senyatanya telah dilaksanakan desa cenderung merupakan urusan rutin, turun temurun, dan telah menjadi kebiasaan dilakukan oleh pemerintah desa sejak lama. Ketentuan kewenangan 
yang tidak jelas serta implementasinya yang cenderung seadanya, menyebabkan masa depan kemandirian desa tidak jelas pula.

Dalam hal ini, prinsip subsidiaritas secara teoritis bisa menjadi pertimbangan. Prinsip subsidiaritas didefinisikan sebagai prinsip bahwa segala masalah seharusnya diselesaikan pada tingkat paling kecil/rendah, kecuali ada alasan yang memaksakan masalah tersebut perlu diselesaikan pada tingkat yang lebih luas. Norton (1997), Smith (1985), Leonard (1983), dan Ditjen PMD (2007) melihat pentingnya prinsip subsidiaritas yang mendekatkan pembuatan keputusan kepada tingkat lokal. Selain itu, terdapat beberapa kriteria dalam rangka mewujudkan proporsionalitas dalam pembagian urusan pemerintahan digunakan kriteria, yaitu: kriteria eksternalitas, kriteria akuntabilitas, dan kriteria efisiensi. Aspek-aspek tersebut selama ini belum dilaksanakan secara konsisten.

Secara normatif, terdapat sejumlah perubahan regulatif pada saat berlakunya UU Nomor 32/2004 dengan peraturan perundang-undangan sebelumnya (UU Nomor 22/1999 dan UU Nomor 5/1979). Pada prinsipnya, dalam ketiga periode undang-undang belum dapat mewujudkan kedudukan desa yang kuat. Desa tetap menjadi sub-ordinasi pemerintah kabupaten, yang pada kasus-kasus tertentu menjadi sasaran eksploitasi pemerintah supra desa. Realitas semacam itu tidak berbeda jauh dibanding kondisi desa sejak pada masa kolonial (Ali, 2007, Marbun, 1988). Ketika berlaku UU Nomor 22/1999 dan UU Nomor 32/2004, kebebasan (otonomi) desa terhambat oleh kewenangan, kapasitas, dan akses sumber daya yang tidak berpihak kepada desa. Jadi, meskipun perubahan dalam regulasi berdampak pada perubahan struktur dan fungsi kelembagaan pemerintahan desa, tetapi dampaknya terhadap praktik di masyarakat tidak seluruhnya berpengaruh signifikan. Sebagai bagian dari lembaga formal kenegaraan, perubahan struktur dan fungsi kelembagaan pemerintahan desa berhubungan erat dengan desain peraturan perundangundangan. Setiap perubahan klausul dalam peraturan perundang-undangan berpotensi merubah struktur dan fungsi kelembagaan.

Terkait perubahan struktur dan fungsi kelembagaan pemerintahan desa, ada beberapa perubahan ketentuan terkait penyelenggaraan pemerintahan di desa yang dapat dipetakan menjadi tujuh aspek, yaitu: struktur (unsur) pemerintahan desa; kepala desa; sekretaris desa, kepala dusun, dan kepala urusan; lembaga perwakilan (BPD); peraturan desa; keuangan desa; serta kedudukan keuangan kepala desa dan perangkat desa (Suharto, 2012a).

Perubahan atas komposisi (unsur) dan hirarki lembaga pemerintahan desa bisa menimbulkan potensi konflik terkait perubahan orientasi kerja perangkat desa dan kemungkinan penurunan kinerja aparat pemerintahan desa. Perubahan pertanggung-jawaban, masa kerja, dan kesejahteraan kepala desa bisa membawa permasalahan terkait perubahan orientasi kepala desa yang cenderung ke atas, penentangan atas perubahan masa kerja dan sistem bengkok yang menyebabkan berkurangnya penghasilan kepala desa. Selanjutnya, perubahan status sekretaris desa menjadi PNS dan perubahan SOTK sekretaris desa, kepala urusan dan kepala dusun menimbulkan sejumlah permasalahan seperti penetapan status kepegawaian yang belum jelas, potensi ambivalensi pelaksanaan tugas antara kepada kepala desa dengan camat atau tata kerja sekretaris desa yang lebih berorientasi kepada pemerintah di atasnya, berkurangnya kreativitas dalam membangun wilayah, potensi konflik dan kecemburuan sosial antara sekretaris desa dengan perangkat desa lain, serta berkurangnya eksistensi posisi sekretaris desa di hadapan kepala urusan dan kepala dusun. Namun terdapat pula potensi dampak positifnya, yakni sistem administrasi desa semakin berkembang baik.

Dalam hal perubahan nama Badan Permusyawaratan Desa (BPD), mekanisme rekrutmen anggota, dan perubahan tugas/fungsi bisa menyebabkan permasalahan terkait berkurangnya kedaulatan rakyat dalam memilih anggota BPD dan menyalurkan aspirasinya, dominansi elit-elit lama di pemerintahan desa, dan berkurangnya akuntabilitas kerja anggota BPD terhadap masyarakat, serta eksistensi BPD menjadi lemah. Dalam konteks tersebut, akuntabilitas perangkat desa (termasuk kepala desa) juga semakin berkurang. Kepala desa dan perangkat desa cenderung berorientasi kepada pemerintah kabupaten daripada stakeholders di desa.

Sedangkan perubahan istilah dan mekanisme penyusunan peraturan desa dapat menimbulkan masalah dalam hal birokratisasi penyusunan peraturan desa, keterbatasan keleluasaan desa, dan kemungkinan rendahnya penyerapan aspirasi masyarakat dalam peraturan desa. Berkenaan perubahan bagi hasil/perimbangan keuangan dan sumber pendapatan desa, terdapat potensi masalah seperti konsistensi dan komitmen untuk memberikan bagi hasil/perimbangan keuangan lebih layak kepada desa tidak terpenuhi, potensi penurunan pendapatan desa, dan kemungkinan berkurangnya keleluasaan desa dalam mengelola anggaran. Potensi masalah yang timbul dari perubahan komposisi penghasilan kepala desa/perangkat desa adalah kemungkinan penurunan penghasilan kepala desa dan perangkat desa, kesenjangan penghasilan kepala desa dan perangkat desa, kecenderungan berkurangnya motivasi kepala desa. Perubahan kedudukan keuangan kepala desa dan perangkat desa pada garis besarnya telah menggeser arah desentralisasi politik menuju desentralisasi administrasi.

Dari perspektif teoritis, untuk membahas dan menganalisis struktur dan fungsi kelembagaan pemerintahan desa agar lebih efektif dalam mendorong kemandirian desa, dapat dicermati dari pendekatan pembangunan lembaga. Pemerintahan desa, mengacu konsepsi Henry Mintzberg tentang lima bagian pokok atau fungsi dari organisasi bisa 
diidentikkan sebagai operating core. Operating core menjalankan pekerjaan pokok organisasi -input, pengolahan, output, tugas dukungan langsung yang terkait dengan memproduksi barang atau jasa. Fungsifungsi dalam organisasi yang disampaikan Mintzberg (1979) sebaiknya ada pada setiap organisasi, meskipun tidak harus selalu ada dalam struktur organisasi dan hanya dilaksanakan oleh personil secara fungsional.

Pilihan struktur sederhana bagi kelembagaan pemerintahan desa tersebut dipandang tepat jika didasari karakteristik subyek, obyek, lingkungan, tugas dan fungsi, serta kemampuan keuangan desa. Karakter aktor (aparat pemerintahan desa) dari sisi kuantitas maupun kualitas terbatas. Demikian pula sasaran dari pelayanan dari pemerintahan desa (masyarakat) juga tidak terlalu kompleks. Sedangkan tugas/fungsi pemerintahan desa tidak terlalu rumit/kompleks. Sementara kemampuan keuangan desa terbatas. Hal-hal tersebut menjadi pertimbangan pemilihan struktur sederhana. Karena struktur sederhana juga memiliki kelemahan-kelemahan maka perlu dikombinasikan dengan struktur fungsional. Sehingga meskipun struktur kelembagaan berbentuk sederhana, tapi bersifat fungsional.

Kurang berfungsinya kelembagaan desa, berpengaruh terhadap upaya pembangunan lembaga. Untuk itu, pembangunan lembaga diperlukan untuk memberdayakan pemerintahan desa. Pembangunan lembaga dapat dirumuskan sebagai perencanaan, penataan, dan bimbingan dari organisasi-organisasi baru atau yang disusun kembali yang (a) mewujudkan perubahan-perubahan dalam nilai-nilai, fungsi-fungsi, teknologi-teknologi fisik, dan/atau sosial, (b) menetapkan, mengembangkan, dan melindungi hubungan-hubungan normatif dan pola-pola tindakan yang baru, dan (c) memperoleh dukungan dan kelengkapan dalam lingkungan tersebut (Eaton, 1986:24). Ada dua kelompok variabel atau faktor yang penting untuk membimbing kegiatan pembangunan lembaga. Yaitu variabel-variabel lembaga yang pada dasarnya menyangkut organisasi itu sendiri, dan variabel-variabel kaitan yang berhubungan terutama dengan hubungan-hubungan ekstern.

Dalam konteks model pembangunan lembaga, aspek politik dianggap strategis karena akan menghasilkan produk yang berupa regulasi (peraturan perundang-undangan). Persoalan regulasi ini penting bagi desa, karena pemerintahan desa menjadi bagian dari struktur (organisasi) formal kenegaraan. Intervensi atas peraturan perundang-undangan akan memberikan pengaruh signifikan bagi desa. Sebagai contoh, regulasi atas penguatan kedudukan desa dapat berdampak pada kewenangan, keuangan, dan sumber daya yang lain, kualitas program, termasuk kemandirian desa. Aspek politik dapat dikatakan sebagai respon kebijakan atau alat "intervensi" dari pemerintahan supra desa.

Kemandirian desa tidak hanya persoalan pemberian pengakuan dan kesempatan kepada desa untuk mengatur urusan rumah tangga dan kepentingan masyarakat setempat, namun juga dukungandukungan yang lain. UU Nomor 32/2004 telah memberi pengakuan terhadap kewenangan/hak asalusul desa. Hak asal usul masyarakat desa sebagai kesatuan masyarakat hukum mencakup; hak membentuk peraturan atau tata nilai; hak membentuk lembaga-lembaga yang berfungsi menyusun peraturan maupun yang melaksanakan peraturan; hak merumuskan kepentingan-kepentingan masyarakat sendiri, yaitu kepentingan dalam aspek keagamaan/kepercayaan dan adat istiadat dan kepentingan kemasyarakatan (kepemerintahan); hak atas sumber-sumber daya di dalam teritorialnya, terutama air dan tanah; serta hak menentukan pemimpin sendiri. Dalam konteks ini, hal-hal tersebut dirumuskan dalam dua pengelompokan, yakni desentralisasi yang bersifat dan memiliki tujuan administratif/ekonomi (kemandirian administratif/ekonomi; dilihat dari struktur dan komposisi APBDesa, keleluasaan desa dalam mengelola pendapatan desa, aset dan usaha desa, serta kemandirian ekonomi masyarakat dalam pembangunan atau keswadayaan); dan politik (kemandirian politik; dilihat dari proses rekrutmen/pembinaan aparatur, pertanggung-jawaban aparatur, perwujudan hak-hak politik/partisipasi masyarakat, kemandirian dalam pembuatan kebijakan, kebebasan dalam mengekspresikan hak asal-usul desa dan adat istiadat) (Suharto, 2012a).

Dari aspek struktur dan komposisi Anggaran Pendapatan dan Belanja (APB) desa, kontribusi PAD desa terhadap seluruh pendapatan desa di desa lokasi penelitian tampak masih sangat minim dan terbatas. Rendahnya PAD desa terutama disebabkan terbatasnya kepemilikan tanah kas desa (bengkok). Pemerintah desa dan masyarakat desa pada realitasnya tidak mempunyai banyak kesempatan membiayai pembangunan dari APBDesa karena kondisi keuangan yang serba kekurangan. Tingginya jumlah maupun persentase bantuan/subsidi pendanaan dari pemerintah supra desa terhadap anggaran desa selama ini memperlihatkan telah terjadi ketimpangan anggaran di desa sehingga menjadikan desa dalam posisi tergantung (dependen). Menyangkut pengelolaan aset dan usaha desa, pemerintah desa belum bisa maksimal mandiri mengelola dan mendapat hasilnya. Kepemilikan aset dan usaha desa masih sangat terbatas. Pengelolaan aset selain tanah kas (bengkok) dan usaha desa belum dapat menjadi sumber pemasukan andalan bagi desa, pemerintah desa belum bisa maksimal mandiri mengelola dan mendapat hasilnya. Sementara itu, kemandirian ekonomi masyarakat dalam pembangunan desa rata-rata sudah berkembang baik. Terbukti antara lain dari tingkat swadaya masyarakat dalam pembangunan wilayahnya cenderung terus meningkat. Kemandirian masyarakat tersebut dipengaruhi oleh potensi masyarakat. Sedangkan potensi masyarakat banyak ditentukan oleh sosial ekonomi masyarakat. 
Gambaran mengenai kemandirian politik desa terutama terlihat melalui karakteristik pemerintah desa dan BPD. Persoalan rekrutmen (pengisian) aparat pemerintah desa dan BPD pada era sekarang lebih menekankan pada desentralisasi administratif. Hal tersebut ditandai oleh model rekrutmen sebagian besar lembaga-lembaga tersebut yang tidak lagi melalui pemilihan langsung oleh masyarakat, tapi melalui sistem pengangkatan atau melalui dewan pemilih. Dari segi efektivitas pemerintahan, realitas tersebut akan bermanfaat karena meminimalisir "kegaduhan" politik dari banyak orang/pihak dan mengalihkannya ke sedikit orang/pihak. Namun hal itu berdampak negatif terhadap berkurangnya kemandirian (kedaulatan) politik desa/masyarakat. Sebab setiap masyarakat tidak bisa menyampaikan pilihan politiknya dengan langsung. Di bagian lain, terdapat campur tangan pemerintah supra desa dalam pembinaan aparatur pemerintah desa. Pembinaan kepada aparat pemerintah desa bukan hanya dilakukan pemerintah kecamatan, tapi juga dilakukan langsung oleh pemerintah kabupaten. Pembinaan yang dilakukan pemerintah supra desa kepada aparat pemerintah desa selama ini berhubungan dengan tugas yang diamanatkan dalam peraturan perundangundangan. Pembinaan tersebut dimaksudkan untuk memperlancar tugas-tugas pemerintahan di desa. Artinya, pemerintah berusaha menjalankan desentralisasi administratif melalui peningkatan efektivitas pemerintahan desa.

Orientasi pertanggung-jawaban aparatur pemerintah desa yang lebih condong bergeser ke atas (supra desa) berdampak pada pergeseran penyelenggaraan pemerintah desa ke arah desentralisasi administratif. Pergeseran pertanggungjawaban kepala desa dari BPD ke bupati, pergeseran pertanggung-jawaban administrasi kepegawaian sekretaris desa dari kepala desa ke bupati, dan pergeseran pertanggung-jawaban tugas kepala urusan dari sekretaris desa ke kepala desa, merupakan bukti bahwa perspektif desentralisasi administrasi semakin menguat, yang berdampak terhadap berkurangnya kemandirian politik desa (kalangan bawah). Orientasi pertanggung-jawaban yang lebih besar ke pemerintah kabupaten bisa dimaknai sebagai bentuk pengurangan kedaulatan desa.

Terkait kebebasan dalam pembuatan kebijakan, mekanisme Musyawarah Perencanaan Pembangunan Desa (Musrenbangdes) yang diharapkan menjadi pintu masuk bagi penyampaian aspirasi (aspek demokratisasi) masyarakat, saat ini justru menyebabkan keputus-asaan masyarakat karena perencanaan pembangunan melalui Musrenbangdes seringkali tidak jelas implementasinya. Hal tersebut bisa terjadi disebabkan, pada kenyataannya desa tidak memiliki cukup dana untuk membiayai pembangunan. Permasalahan lain, terdapat ketidak-sesuaian antara hasil Musrenbangdes yang bersifat spasial dengan hasil yang bersifat sektoral di tingkat daerah, dan ketiadaan akses ke elit pengambil kebijakan untuk mempengaruhi keputusan kebijakan alokasi pendanaan.

Dalam hal kebebasan mengekspresikan hak asal-usul desa dan adat istiadat, regulasi/peraturan perundang-undangan telah memberikan kesempatan untuk melaksanakannya. Baik dalam batasan konseptual desa maupun ketentuan normatifnya, peraturan perundang-undangan pada era UU Nomor 32/2004 dan UU Nomor 22/1999 mengakui dan menghormati adat istiadat dan lembaga adat, serta mengamanatkan untuk menetapkan berbagai kebijaksanaan dalam upaya pemberdayaan, pelestarian dan pengembangan adat istiadat dan lembaga adat di wilayah desa. Dalam konteks regulasi tersebut, kemandirian politik desa, khususnya untuk mengekspresikan hak asal-usul dan adat istiadat desa, sudah terjamin. Persoalannya, struktur dan kondisi yang ada tidak memungkinkan optimalisasi atas pelaksanaan hak asal-usul dan adat istiadat desa. Gaya dan tuntutan hidup masyarakat pada kenyataannya telah berkontribusi menggusur eksistensi adat istiadat yang dahulu ada. Perspektif masyarakat dalam melihat adat istiadat sudah bergeser dari hal yang bersifat filosofis ke hal pragmatis.

Perubahan struktur dan fungsi kelembagaan pemerintahan desa pada kenyataannya bukan menjadi faktor tunggal yang mempengaruhi kemandirian desa. Beberapa perubahan struktur dan fungsi kelembagaan pemerintahan desa memang memberikan dampak terhadap kemandirian desa, namun sebagian diantaranya tidak berdampak signifikan. Persoalan kemandirian desa seringkali justru diakibatkan oleh faktor-faktor di luar struktur dan fungsi kelembagaan.

Dalam hal mencermati persoalan kemandirian desa, akan relevan bila melihat pendapat Smith (1985) bahwa pelaksanaan desentralisasi bukan semata-mata suatu proses teknik, administrasi, demi efisiensi dan efektivitas, melainkan merupakan proses interaksi yang dinamik dari berbagai faktor, yang sering sulit untuk diperhitungkan terlebih dahulu yang sering disebut sebagai process of political interaction. Pendapat Smith tersebut tidak berbeda jauh dengan pernyataan Cheema dan Rondinelli (1983:92) yang menyebutkan bahwa desentralisasi adalah konsekuensi dari keputusan politik dan administratif. Sehingga, selain melibatkan aksi-reaksi antara sisi "agensi dan struktur", terdapat satu variabel yang menentukan yaitu variabel supra desa (pemerintah tingkat atas) yang berperan besar dalam mendesain desentralisasi desa.

Hasil penelitian ini menekankan bahwa pelaksanaan desentralisasi perlu memperhatikan karakter, kapasitas, potensi, dan kebutuhan setempat. Sehingga desentralisasi atau penyerahan kewenangan/urusan tidak diberlakukan sama untuk setiap desa. Demikian pula tidak semua desa memiliki bentuk yang sama. Berdasarkan hasil dari penelitian, maka bentuk-bentuk desa yang dirumuskan harus memenuhi prinsip-prinsip sebagai berikut (Suharto dkk., 2012b). 
1. Memungkinkan pengakomodasian terhadap keragaman desa. Sehingga konsep yang disusun harus mempunyai pendekatan optional village, bukan default village (desa baku). Di sisi lain, keragaman desa tidak mengesampingkan fungsi dan peran negara (pemerintah) dalam menjamin negara kesatuan, pembangunan bangsa, dan kesejahteraan masyarakat.

2. Menghindari terjadinya marginalisasi terhadap desa (terutama masyarakatnya). Sehingga bentuk desa yang disusun tidak menyebabkan kepentingan atau kebutuhan masyarakat desa terabaikan. Sebaliknya, pemerintahan dan pembangunan desa dapat lebih terjamin.

3. Di desa menjamin adanya dua prinsip, local selfgovernment dan self-governing community. Sementara yang berstatus local state government berubah menjadi kelurahan.

4. Hubungan interdependensial berlangsung dalam relasi kekuasaan, kewenangan, keuangan serta sosio-psikologis yang proporsional antara desa dan supra-desa merupakan hal penting.

5. Menjamin implementasi desentralisasi politik dan desentralisasi administratif/ekonomi, sehingga dapat mewujudkan kemandirian desa (perspektif politik dan administratif/ekonomi).

Berdasar hal tersebut, dapat disampaikan pilihan bentuk-bentuk desa sebagai berikut:

1. Desa otonom. Merupakan desa yang menjalankan perspektif desentralisasi politik dan desentralisasi administratif. Desa-desa yang memiliki potensi, kapasitas, karakter, dan kebutuhannya memadai dikembangkan menjadi desa otonom dengan menyelenggarakan urusan/kewenangan berdasarkan prinsip subsidiaritas serta kriteria eksternalitas, akuntabilitas, dan efisiensi. Desa otonom mendapatkan akses terhadap sumber daya (SDM, keuangan, dan saran/prasarana) yang diperlukan dalam penyelenggaraan pemerintahan. Hubungan pemerintahan dengan supra desa bersifat interdependensial.

2. Desa administrasi (kelurahan). Desa administrasi dikembangkan dari desa yang kurang memiliki potensi, kapasitas, karakter, atau kebutuhan memadai. Desa administrasi merupakan desa yang menjalankan perspektif desentralisasi administratif, dan tidak menjalankan perspektif desentralisasi politik. Desa administrasi menjadi bagian (sub-ordinasi) dari struktur pemerintahan supra desa.

3. Desa semi otonom. Desa semi otonom merupakan pilihan bagi desa yang dari perspektif desentralisasi politik masih kuat (misal adanya adat istiadat atau hak asal-usul yang masih bertahan), tetapi dari perspektif desentralisasi administratif/ekonomi (misal kapasitas dan potensi ekonomi desa) tidak memadai. Sehingga dalam desa semi otonom terdapat dua struktur desa, yakni desa administrasi yang menyelenggarakan

desentralisasi administratif/ekonomi, dan desa adat yang menyelenggarakan desentralisasi politik. Desa adat dan desa administrasi memiliki hubungan sejajar dan bersifat interdependensial. Desa administrasi dalam desa semi otonom merupakan bagian/sub ordinasi dari pemerintahan supra desa.

\section{SIMPULAN}

Berdasarkan pembahasan penelitian, maka dapat dirumuskan beberapa simpulan. Pertama, esentralisasi politik pada saat berlaku UU Nomor 5/1979 dalam tataran regulatif maupun empiris berlangsung dengan sangat minimal. Ketika berlaku UU Nomor 22/1999 desentralisasi politik berlangsung dinamis. Sedangkan pada era berlakunya UU Nomor 32/2004, desentralisasi politik dan administratif secara regulatif/empirik dicoba diseimbangkan dengan mengurangi penekanan pada desentralisasi politik.

Kedua, perubahan struktur dan fungsi kelembagaan pemerintahan desa pada prinsipnya mengikuti konstruksi atau titik tekan arah desentralisasi (perspektif administratif dan perspektif politik).

Ketiga, kemandirian desa dapat dikelompokkan menurut kemandirian administratif/ekonomi (dilihat dari struktur dan komposisi APBDesa, keleluasaan desa dalam mengelola pendapatan desa, aset dan usaha desa, serta kemandirian ekonomi masyarakat dalam pembangunan atau keswadayaan); dan kemandirian politik (dilihat dari proses rekrutmen/pembinaan aparatur, pertanggung-jawaban aparatur, perwujudan hak-hak politik/partisipasi masyarakat, kemandirian dalam pembuatan kebijakan, kebebasan dalam mengekspresikan hak asal-usul desa dan adat istiadat).

Keempat, pergeseran penekanan pada desentralisasi administratif secara signifikan mengurangi kemandirian politik, tetapi tidak secara signifikan meningkatkan kemandirian administratif.

Kelima, pelaksanaan desentralisasi desa perlu memperhatikan karakter, kapasitas, potensi, dan kebutuhan setempat. Terdapat variasi bentuk-bentuk desa dengan prinsip: memungkinkan pengakomodasian terhadap keragaman desa; menghindari terjadinya marginalisasi terhadap desa (terutama masyarakatnya); menjamin adanya prinsip local self-government dan self-governing community; menjamin hubungan interdependensial yang berlangsung dalam relasi kekuasaan, kewenangan, keuangan serta sosio-psikologis yang proporsional antara desa dan supra-desa; dan menjamin implementasi desentralisasi politik dan desentralisasi administratif/ekonomi. 


\section{DAFTAR PUSTAKA}

Ali, Madekhan. 2007. Orang Desa, Anak Tiri Perubahan. Malang: Averroes Press

Antlov, Hans dan Sven Cedderoth. 2001. Kepemimpinan Jawa: Perintah Halus, Pemerintahan Otoriter. Jakarta: Yayasan Obor

Cheema, G. Shabbir dan Dennis A. Rondinelli. 1983. Decentralization and Development: Policy Implementation in Developing Countries. Beverly Hills : Sage Publication

Ditjen PMD; Direktorat Pemerintahan Desa dan Kelurahan Depdagri. 2007. "Naskah Akademik RUU tentang Desa". Jakarta

Eaton, Joseph W. (ed.). 1986. Pembangunan Lembaga dan Pembangunan Nasional; dari Konsep ke Aplikasi. Jakarta: UI-Press

Eko, Sutoro. (ed.). 2005. Manifesto Pembaharuan Desa, Persembahan 40 tahun STPMD “APMD”. Yogyakarta: APMD Press . 2005. "Masa Lalu, Masa Kini dan Masa Depan Otonomi Desa", dalam Wignosubroto, Soetandyo dkk., 2005, Pasang Surut Otonomi Daerah, Sketsa Perjalanan 100 Tahun. Jakarta: Institue for Local Government.

Leonard, David K. 1983. "Interorganizational Linkages for Decentralized Rural Development: Overcoming Administrative Weakness," dalam G. Shabbir Cheema, dan Dennis A. Rondinelli (eds.). Decentralization and Development, Policy Implementation in Developing Countries. California: Sage Publication, Inc.

Manan, Bagir. 2004. Menyongsong Fajar Otonomi Daerah. Yogyakarta: Pusat Studi Hukum Fakultas Hukum UII.

Marbun, BN. 1988. Proses Pembangunan Desa, Menyongsong tahun 2000. Cetakan Keempat (edisi revisi). Jakarta: Penerbit Erlangga.

Mas'oed, Mohtar. 2003. Politik, Birokrasi dan Pembangunan. Yogyakarta: Pustaka Pelajar.

Mintzberg, Henry. 1979. "The Five Basic Part of the Organization", dalam Jay M. Shafritz, Ott J. Steven, Classics of Organization Theory. Fourth Edition. USA: Wadsworth Publishing Company.

Norton, Alan. 1997. International Handbook of Local and Regional Government, A Comparative Analysis of Advanced Democracies. UK: Edward Elgar Publishing Limited.

Santoso, Purwo. 2003. "Menuju Tata Pemerintahan dan Pembangunan Desa dalam Sistem Pemerintahan Daerah: Tantangan bagi DPRD," dalam Abdul Gaffar Karim (ed.). 2003. Kompleksitas Persoalan Otonomi Daerah di Indonesia. Yogyakarta: Pustaka Pelajar

Smith, Brian C. 1985. Decentralization: The Territorial Dimension of the State. London: George Allen and Unwin.
Suharto, Didik G. 2012a. Dampak Perubahan Struktur dan Fungsi Kelembagaan Pemerintahan Desa terhadap Kemandirian Desa. Disertasi. Tidak dipublikasikan.

; Pawito; dan Muktiyo Widodo. 2012b. Pengembangan Otonomi Desa dengan Pendekatan Desentralisasi. Laporan Penelitian Hibah Fundamental. Tidak dipublikasikan.

Tjondronegoro, Soediono MP. 1999. Keping-keping Sosiologi dari Pedesaan. Jakarta: Ditjen Dikti Depdikbud.

USAID DRSP. 2006. "Desentralisasi 2006: Membedah Reformasi Desentralisasi di Indonesia". Ringkasan Laporan. Agustus 2006.

Zuhro, R. Siti dkk. 2009. Demokrasi Lokal : Perubahan dan Kesinambungan Nilai-nilai Budaya Politik Lokal di Jawa Timur, Sumatera Barat, Sulawesi Selatan dan Bali. Yogyakarta: Ombak. 